\title{
Effect of tobacco on periodontal disease and oral cancer
}

\author{
Yixin Zhang', Jinxiu He', Bing He², Ruijie Huang ${ }^{1 *}$, Mingyun $\mathrm{Li}^{1 *}$
}

\begin{abstract}
INTRODUCTION Periodontal disease and oral cancer are common health hazards. Epidemiological investigations show that smoking, periodontal disease and oral cancer are closely related. Tobacco is one of the major risk factors for periodontitis and oral cancer.
\end{abstract}

METHODS A systematic literature review was performed. To identify relevant studies, the following online databases were searched using specific keywords: PubMed, Web of Science and CNKI.

RESULTS Tobacco not only possesses an addictive effect, but it aggravates periodontal disease by promoting the invasion of pathogenic bacteria, inhibiting autoimmune defense, aggravating the inflammatory reaction, and aggravating the loss of alveolar bone. According to current evidence, tobacco significantly aggravates the development and progression of periodontal disease and oral cancer, and periodontal disease may be related to the prevalence of oral cancer.

CONCLUSIONS Clinicians should strongly recommend that smokers undertake a strategy to stop smoking to avoid the exacerbation of nicotine-related periodontal disease and to reduce the incidence of oral cancer.

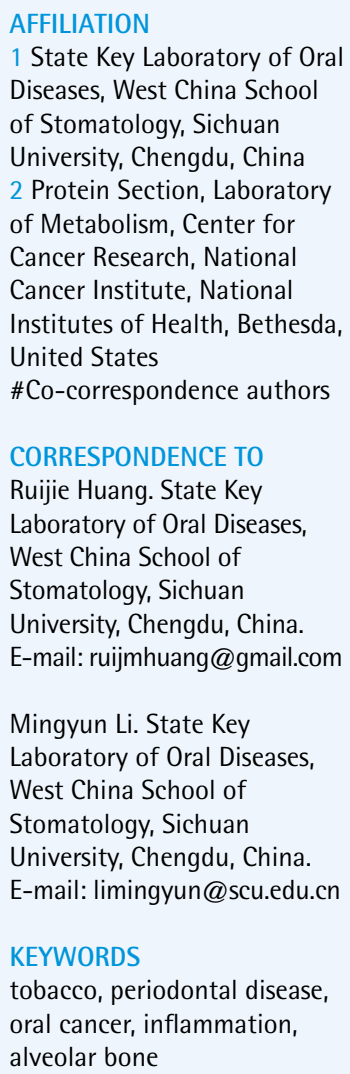

1 State Key Laboratory of Oral Diseases, West China School of Stomatology, Sichuan University, Chengdu, China 2 Protein Section, Laboratory of Metabolism, Center for Cancer Research, National Cancer Institute, National Institutes of Health, Bethesda, United States

\#Co-correspondence authors

CORRESPONDENCE TO

Ruijie Huang. State Key Laboratory of Oral Diseases, West China School of Stomatology, Sichuan University, Chengdu, China.

E-mail: ruijmhuang@gmail.com

Mingyun Li. State Key Laboratory of Oral Diseases, West China School of Stomatology, Sichuan University, Chengdu, China.

E-mail: limingyun@scu.edu.cn

KEYWORDS

tobacco, periodontal disease, oral cancer, inflammation, alveolar bone

Received: 17 December 2018 Revised: 2 April 2019

Accepted: 5 April 2019

\section{INTRODUCTION}

Cigarette smoking is a well-established risk factor for periodontal disease and it is the strongest factor among the modifiable ones ${ }^{1}$. Research evidence suggests that smokers have a higher tendency to problems such as teeth and bone loss and gingival recession compared to non-smokers, and to the formation of periodontal pockets, which increase the probability to suffer from more severe periodontal disease ${ }^{2-5}$. Tobacco can affect the function and proliferation of periodontal cells such as gingival fibroblasts, periodontal membrane cells, periodontal ligament cells and other cells, thus inducing cell apoptosis. It can also affect the invasion of periodontal disease, inhibit the autoimmune defense, and aggravate the inflammation reaction to damage and destroy the alveolar bone. Oral cancer is a common health hazard, which is also closely related to tobacco. This article reviews the relationship among tobacco, periodontal disease and oral cancer. 


\section{METHODS}

PubMed, Web of Science databases and CNKI were selected as the primary databases. Searches were conducted by crossing keywords 'tobacco' and 'nicotine' separately with 'periodontal disease' and 'oral cancer'. Searches were limited to studies in English and published from 1947 to 2019. Inclusion criteria were: articles focused on tobacco and nicotine and focused on any of the six key themes (periodontal disease, oral cancer, inflammation, alveolar bone, periodontal cells, and oral bacterial species) according to the objective of this review. Firstly, titles and abstracts were assessed, and then articles were included or excluded based on their relevance. In this review, clinical, microbiological and immunological data regarding tobacco, periodontal disease and oral cancer were collected, compared, analyzed and studied, and the relationship among them was summarized.

\section{RESULTS and DISCUSSION}

\section{Clinical findings}

Periodontal disease is a common chronic inflammatory disease that causes tooth loss in adults, and it is characterized by the destruction of the supporting structures of teeth including the gingiva, cementum, periodontal ligament, and alveolar bone ${ }^{6,7}$. It is now recognized that periodontal disease is a multifactorial disease in which plaque is the triggering factor of periodontal disease. Common risk factors for periodontal disease include gender, poor lifestyle such as smoking habit and alcohol consumption, certain systemic diseases such as diabetes, prediabetes, obesity and metabolic syndrome, and genetic factors ${ }^{8}$. The first observation on the relationship between smoking and periodontal tissues occurred in the1940s, when Pindborg ${ }^{9,10}$ demonstrated that necrotizing ulcerative gingivitis was associated with tobacco consumption. Several epidemiological studies clearly demonstrated a strong association between tobacco use/smoking habit and periodontal diseases in diverse populations ${ }^{11-13}$. In general, evidence indicates that smokers have more severe periodontal diseases, with increased bone attachment and tooth loss, gingival recession, and pocket formation compared to nonsmokers and there is a dose-response relationship between the number of cigarettes smoked per day and odds of periodontal disease ${ }^{14,15}$. The dangers of passive smoking have also been emphasized as some evidence linked passive smoking to diseases and death in non-smokers ${ }^{16}$.

Oral cancer is a common health hazard, with approximately 300378 new patients and 2.7 per 100000 mortality worldwide in 2012; the incidence increased in young and middle-age population groups in recent years ${ }^{1,17,18}$. According to previous reports, oral cancer is the world's sixth most common cancer and squamous cell carcinomais the most prevalent among oral malignancies ${ }^{19}$. Oral cancer is considered as a multi-factor disease, in which tobacco, alcohol and betel quid are the major risk factors ${ }^{17}$. Smoking has a significant epidemiological correlation with oral cancer and plays an important role in its occurrence and development. Smokers are 7 to 10 times more likely to develop oral cancer and 3 times more likely to develop a second primary cancer than nonsmokers $^{20,21}$. In addition, some studies reported a positive correlation between periodontal disease and oral cancer, suggesting that periodontal disease is an independent risk factor for oral cancer, and smoking promotes this correlation $^{22-26}$

\section{Effect of tobacco on periodontal cells}

Periodontal ligament cells (hPDLCs) are the main cell components in the periodontal membrane, and they have chemotactic adhesion, proliferation, biosynthesis and differentiation into cementite and osteoblasts. Various tissues, such as cementum and alveolar bone, are formed, playing an important role in the maintenance, regeneration and repair of tooth support tissues. Table 1 summarizes the effect of tobacco on periodontal cells.

Many of the underlying effects of tobacco products on periodontal tissues may be due to a direct inhibition of normal fibroblast function. Both gingival fibroblasts (hGFs) and periodontal ligament fibroblasts (PDLFs) display reduced cell viability with increasing concentrations of cigarette smoke extract (CSE) and nicotine $^{27,28}$. PDLFs are also more sensitive to nicotine compared with hGFs ${ }^{28}$. Du et al. ${ }^{29}$ indicated that nicotine activates the autophagy of hPDLCs by increasing the number of autophagosomes and by the up-regulation of the autophagy related protein LC3 expression, suggesting that nicotine can increase autophagy of hPDLCs, thus affecting the occurrence and development of smoking related periodontal disease. 
Table 1. The effect of tobacco on periodontal cells

\begin{tabular}{|c|c|c|c|}
\hline Reference & Type of study & Vicrobiological technique & Principal findings \\
\hline Lallier et al. ${ }^{29}$ & In vitro & Fluorescent microscopy & $\begin{array}{l}\text { With increasing concentrations of nicotine HGFs and PDLFs } \\
\text { reduce cell viability }\end{array}$ \\
\hline Yang et al..$^{30}$ & In vitro & $\begin{array}{l}\text { Transmission electron microscope and } \\
\text { immunofluorescence observations }\end{array}$ & Nicotine increases autophagy level of hPDLCs \\
\hline Zhang et al. ${ }^{31}$ & In vitro & RT-PCR & CSE increases the collagen-degrading ability of hGFs \\
\hline Zhou et al. ${ }^{32}$ & In vitro & RT-PCR & $\begin{array}{l}\text { Nicotine and P. gingivalis had an additive effect on human } \\
\text { gingival fibroblast-mediated collagen degradation }\end{array}$ \\
\hline Deveci et al. ${ }^{33}$ & In vitro & Light microscope & $\begin{array}{l}\text { Nicotine disrupts periodontal membrane and prevents tooth } \\
\text { to anchor in dental alveoli by disrupting epithelial structure }\end{array}$ \\
\hline Park et al. ${ }^{34}$ & In vitro & RT-PCR & $\begin{array}{l}\text { The effect of nicotine and lipopolysaccharide on hGFs up- } \\
\text { regulation of SIRT1 mRNA plays an anti-inflammatory and } \\
\text { pro-inflammatory effect }\end{array}$ \\
\hline Brejc et al. ${ }^{36}$ & In vitro & RT-PCR & Nicotine alters periodontal cells directly via nAChRs \\
\hline Moga et al. ${ }^{38}$ & In vitro & Histological examinations & Nicotine exerts dose- and time-dependent cytotoxic effects \\
\hline $\mathrm{Ng}$ et al. ${ }^{39}$ & Clinical & $\begin{array}{l}\text { Cell migration analysis and gene } \\
\text { expression analysis }\end{array}$ & $\begin{array}{l}\text { Cigarette smoking reduces proliferation rate and retarded } \\
\text { migration capabilities of PDLSC }\end{array}$ \\
\hline
\end{tabular}

In addition to the direct damage to cells, a study shows that the combination of CSE increases the collagen-degrading ability of hGFs ${ }^{30}$. Nicotine, as the main active ingredient in tobacco, increases human gingival fibroblast-mediated collagen degradation, in part through the activation of membrane-associated matrix metalloproteinases (MMPs). Indeed, MMP14 and MMP-2 produced by the nicotine-treated human gingival fibroblasts undergo more readily zymogen activation. Nicotine has an additive effect on human gingival fibroblast-mediated collagen degradation when combined with the presence of $P$. gingivalis $^{31}$. Deveci et al. ${ }^{32}$ found that nicotine reduces the production of MMPs, disrupts collagen synthesis and causes periodontitis in rats. They observed that nicotine increases periodontitis by disrupting the periodontal membrane and prevents the anchorage of teeth in the dental alveoli by disrupting the epithelial structure. In addition, the action of nicotine and lipopolysaccharide on SIRT1 mRNA upregulation in hGFs has an anti-inflammatory and proinflammatory effect ${ }^{33}$. Studies show that nicotine may alter periodontal cells directly via nAChRs, leading to pathophysiological effects and the development of tobacco-related diseases in these cells ${ }^{34-36}$.

Cigarette smoking contributes to the development of destructive periodontal diseases and delays the healing process. Moga et al. ${ }^{37}$ isolated four types of cells from human periodontium: gingival ligament stem cells (GLSCs), periodontal ligament stem cells (PDLSCs), gingival tissue stem cells (GTSCs), and alveolar bone stem cells (ABSCs), aiming at assessing the cytotoxic effect of nicotine on periodontal mesenchymal stem cells. They found that nicotine exerts dose- and time-dependent cytotoxic effects. $\mathrm{Ng}$ et al. ${ }^{38}$ hypothesized that the delayed healing process in cigarette smokers is caused by the effected regenerative potential of smoker PDLSC. They cultured PDLSC from teeth extracted from smokers and non-smokers, and they found significantly reduced proliferation rate and retarded migration ability in smoker PDLSC.

\section{Effect of tobacco on bacteria}

Generally, smokers have more calculus deposit than non-smokers, and the calculus from smokers is stiffer and more tightly attached to teeth than that from nonsmokers. Acquired pellicle attaching to a tooth surface is the initial step for dental biofilm formation, followed by bacterial cell attachment to the acquired pellicle ${ }^{39}$. In vitro experiments showed that lower concentrations of nicotine can stimulate oral biofilm formation and influence cell metabolism of biofilm microorganisms ${ }^{40}$. Unfortunately, there are still questions regarding the ability of nicotine in increasing the metabolic activity of microorganisms in the oral cavity. 
Some studies reported no differences in the prevalence of subgingival species between smokers and non-smokers with periodontitis ${ }^{41,42}$. Cogo et al. ${ }^{43}$ performed a study to evaluate the effects of nicotine, cotinine, and caffeine on the viability of some oral bacterial species, and their findings indicate all these compounds in the concentrations used, cannot significantly affect the growth of the oral bacterial strains considered. Moreover, the species considered in their study appear not to metabolize these compounds.

However, some authors showed that smoking increases the prevalence and amount of some oral bacterial strains ${ }^{44}$. Table 2 is a summary of some of the results attesting the factors that increase the bacterial invasiveness due to the presence of tobacco. Streptococcus gordonii (S. gordonii) plays a central role in initiating dental biofilm formation, and in providing binding sites for later colonizers such as $P$. gingivalis, allowing its attachment and the generation of mature biofilm. Huang et al..$^{45}$ found that nicotine stimulates $S$. gordonii planktonic cell growth, biofilm formation, aggregation, and gene expression translated into binding proteins. Furthermore, Shan et al ${ }^{46}$ suggested that nicotine can enhance the growth of Candida albicans (C. albicans) and C. parapsilosisin vitro and influence their adherence to the surface of microplate wells that mimic the tooth surface adherence. These effects may promote later pathogen attachment to tooth surfaces, the accumulation of tooth calculus, and the development of periodontal disease in cigarette smokers.
$P$. gingivalis is an important colonizer of the subgingival crevice and is a major pathogenic agent in the initiation and progression of severe forms of periodontal disease. Moreover, it is found in significantly higher numbers in smokers than in nonsmokers, and infection is more persistent in smokers compared to non-smokers ${ }^{47}$. With this in mind, the consequences of the presence of $P$. gingivalis are discussed separately. Cogo et al. ${ }^{48}$ performed a study indicating that cotinine and nicotine interfere with the ability of $P$. gingivalis to invade the epithelial cells. High doses of CSE and nicotine inhibit bacterial growth, while low doses can increase the biofilm formation of the gingival porphyrins and associated actinobacteria, as confirmed by previous reports ${ }^{40,49}$. Cogo et al. ${ }^{50}$ successfully identified the expression of different proteins by liquid chromatography mass spectrometry and main sequence database of the mascot search engine, and used the DAVID tool to carry out the genetic ontology. Their results revealed the changes in the proteome of $P$. gingivalis following exposure to nicotine and cotinine, suggesting that these substances may modulate, with minor changes, protein expression. However, Baek et al. ${ }^{51}$ suggested that nicotine did not significantly affect total protein expression. It cannot be excluded that a significant change in the protein profile actually occurred, but it was not detectable by visual inspection of gel electrophoresis.

Considering the limitations of the current study, it can only be concluded that nicotine has the potential to elicit a stress reaction, and therefore may serve

\section{Table 2. Tobacco increases bacterial invasiveness}

\begin{tabular}{|c|c|c|c|}
\hline Reference & Type of study & Vicrobiological technique & Principal findings \\
\hline $\begin{array}{l}\text { Haffajee } \\
\text { et al. }{ }^{45}\end{array}$ & Clinical & PCR & $\begin{array}{l}\text { Smoking increases the likelihood and proportion of certain } \\
\text { microbial epidemics }\end{array}$ \\
\hline Huang et al. ${ }^{46}$ & In vitro & RT-PCR & $\begin{array}{l}\text { Nicotine stimulates S. gordonii planktonic cell growth, biofilm } \\
\text { formation, aggregation, and gene expression of binding proteins }\end{array}$ \\
\hline Shan et al. ${ }^{47}$ & In vitro & RT-PCR & $\begin{array}{l}\text { Nicotine enhances the growth of } C \text {. albicans and } \\
\text { C. parapsilosis and influences their adherence }\end{array}$ \\
\hline Cogo et al. ${ }^{49}$ & In vitro & Colony-forming unities & $\begin{array}{l}\text { Nicotine and cotinine interfere with } P \text {. gingivalis ability to } \\
\text { associate and invade the epithelial cells }\end{array}$ \\
\hline Liu et al. ${ }^{50}$ & In vitro & Absorption photometry & $\begin{array}{l}\text { Small doses of nicotine and mecamylamine can increase the } \\
\text { biofilm formation of the gingival porphyrins and associated } \\
\text { actinobacteria }\end{array}$ \\
\hline Cogo et al. ${ }^{51}$ & In vitro & $\begin{array}{l}\text { Liquid chromatography-mass } \\
\text { spectrometry and primary sequence }\end{array}$ & $\begin{array}{l}\text { Exposure to nicotine and cotinine, the proteome of } \\
\text { P. gingivalis changes }\end{array}$ \\
\hline
\end{tabular}


as an environmental modulating factor for bacterial metabolism and survival.

\section{Tobacco reduces periodontal tissue immune defense}

The multiple defence barriers of the periodontal tissue are represented by the epithelial barrier, immune cells, saliva and gingival fluid. This mechanism plays an important role in the persistence of dental plaque in the gingival furrow and the protection of periodontal tissue from bacterial invasion and destruction. Table 3 summarizes the mechanisms by which tobacco can reduce the immune defense of periodontal tissues.

Epithelial cells are recognized as the first line of defence against bacterial infection and environmental harmful stimuli such as cigarette smoke (CS). Although previous studies explored the effects of nicotine on host cells, mechanisms used by CS to affect cellular functions remain uncertain. $P$. gingivalis alone induces low levels of IL- $1 \beta$ and IL-8 on epithelial cells, but high levels of both cytokines are produced with the addition of neutrophils. CSE exposure reduces the pro-inflammatory cytokine burden, which may promote $P$. gingivalis survival and invasion ${ }^{52}$. Moreover, cell migration and proliferation are key aspects of many biological processes, including wound healing and tissue regeneration ${ }^{53}$. During the wound healing process, epithelial cells at the wound edges start to migrate and proliferate to cover the denuded area. This cell migration is necessary for re-epithelialization. The Imamura et al. ${ }^{54}$ study demonstrated that low concentrations of CSE increased the invasion of human gingival epithelial cells infected with $P$. gingivalis and induced changes in cytoskeleton and integrin expression, thereby modulating cell migration. Furthermore, they found that nicotine in CSE exerts effects on the migration of human gingival epithelial cells through the activation of the MAPK ERK1/2 and p38 signaling pathways ${ }^{55}$.

It has been reported that neutrophils pretreated with CSE exhibited reduced speed, velocity and directionality compared to untreated neutrophils ${ }^{56}$. In addition, tobacco affects the secretion of cytokines and inflammatory mediators from immune cells such as neutrophils and mononuclear cells. Tobacco may impair the chemotaxis and phagocytosis of neutrophils, modifying the production of cytokines or inflammatory mediators ${ }^{57}$. The functional roles of $\mathrm{T}$ cells in periodontal disease lesions remain to be elucidated. In human studies, $T$ cells infiltrating

Table 3. Tobacco reduces periodontal tissue immunity

\begin{tabular}{|c|c|c|c|}
\hline $\begin{array}{l}\text { Defense barriers of } \\
\text { periodontal tissuce }\end{array}$ & Reference & Vicrobiologieal technique & Principal findings \\
\hline \multirow[t]{2}{*}{ Epithelial barrier } & $\begin{array}{l}\text { Bondy-Carey } \\
\text { et al. }{ }^{53}\end{array}$ & $\begin{array}{l}\text { Bacterial culture and cytokine } \\
\text { profiling }\end{array}$ & $\begin{array}{l}\text { CSE-exposure promotes } P \text {. gingivalis survival and invasion by } \\
\text { reducing the pro-inflammatory cytokine burden }\end{array}$ \\
\hline & Imamura et al. 55,56 & MAPK and PCR & $\begin{array}{l}\text { Nicotine exerts effects on the migration of human gingival } \\
\text { epithelial cells through the activation of the MAPK ERK } 1 / 2 \\
\text { and p38 signaling pathways }\end{array}$ \\
\hline \multirow[t]{4}{*}{ Immune cells } & White et al. ${ }^{57}$ & $\begin{array}{l}\text { Fluorescence-based assays and } \\
\text { PCR }\end{array}$ & $\begin{array}{l}\text { CSE reduces speed, velocity and directionality relative to } \\
\text { untreated neutrophils }\end{array}$ \\
\hline & Erdemir et al. ${ }^{58}$ & Cell culture & $\begin{array}{l}\text { Tobacco effects the secretion of cytokines and inflammatory } \\
\text { mediators from immune cells, such as neutrophils and } \\
\text { mononuclear cells }\end{array}$ \\
\hline & Ge et al. ${ }^{60}$ & $\begin{array}{l}\text { Cell culture and cytokine and } \\
\text { chemokine detection }\end{array}$ & $\begin{array}{l}\text { Nicotine promotes PDL cell-CD4+T cell-mediated } \\
\text { inflammatory response and matrix degradation }\end{array}$ \\
\hline & Yanagita et al. ${ }^{61}$ & $\begin{array}{l}\text { Cell culture and cytokine and } \\
\text { chemokine detection }\end{array}$ & $\begin{array}{l}\text { DCs in nicotine culture impair T-cell proliferation and reduced } \\
\text { host immunity }\end{array}$ \\
\hline \multirow[t]{3}{*}{$\begin{array}{l}\text { Gingival crevicular } \\
\text { fluid }\end{array}$} & An et al. ${ }^{62}$ & $\begin{array}{l}\text { Enzyme-linked immunosorbent } \\
\text { assay }\end{array}$ & $\begin{array}{l}\text { Nicotine causes vascular endothelial cells to contract, } \\
\text { reducing blood flow, and reducing the immune cells and GCF }\end{array}$ \\
\hline & Bozkurt et al..$^{63}$ & $\begin{array}{l}\text { Enzyme-linked immunosorbent } \\
\text { assay }\end{array}$ & Tobacco reduces leptin levels in GCF in periodontitis \\
\hline & Bunaes et al. ${ }^{65}$ & $\begin{array}{l}\text { Checkerboard DNA-DNA } \\
\text { hybridization }\end{array}$ & $\begin{array}{l}\text { Smoking increases the cytokine and inflammatory in GCF and } \\
\text { aggravates periodontitis }\end{array}$ \\
\hline
\end{tabular}


gingival lesions expressed mRNA for T-helper (Th) $1 /$ Th2 and for regulatory cytokines ${ }^{58}$. Nicotine deteriorates periodontal disease partially by promoting PDL cell-CD4+T cell-mediated inflammatory response and matrix degradation ${ }^{59}$. On the other hand, $P$. gingivalis LPS-stimulated monocyte-derived dendritic cells induced increased proliferation with increasing dendritic cells (DC) number. However, DCs cultured in the presence of nicotine significantly impair T-cell proliferation and reduce host immunity ${ }^{60}$. DCs are key mediators between innate and adaptive immunity, and they stimulate naive $\mathrm{T}$ cells to differentiate to effector T-cell subsets that may be actively involved in the immunopathogenesis of periodontal diseases.

Other effects of smoking are the decrease in blood flow and impairment of revascularization in the periodontal tissues, thereby causing delayed wound healing. Nicotine causes the contraction of vascular endothelial cells ${ }^{61}$, reducing blood flow, making gingivitis less clinically evident and easy to be missed, reduces the immune cells and gingival crevicular fluid (GCF), and may reduce the host immunity during early periodontitis. Leptin emerges as a pleiotropic molecule involved in several physiological and pathological conditions, and higher leptin levels in healthy sites in periodontitis patients may play a protective role against periodontal disease. However, Bozkurt et al. ${ }^{62}$ results suggest that tobacco reduces leptin levels in GCF in periodontitis. Monocyte chemoattractant protein-1 (MCP-1) is involved in the activation and recruitment of inflammatory and immune cells to infected sites, thereby mediating a variety of pathophysiological conditions. Estimation of serum and GCF MCP levels can be a reliable indicator of periodontal disease activity. The Sukumaran et al. ${ }^{63-65}$ study concluded that smoking increases GCF MCP levels, cytokine and inflammatory factors, thus aggravating periodontitis. This last aspect is described in detail in the next section.

\section{Tobacco exacerbates periodontal tissue inflammatory response}

Smoking not only alters the host response, including vascular function, and neutrophil/monocyte activity, but also increases adhesion molecule expression, antibody production, and cytokine and inflammatory mediator release ${ }^{66}$. Table 4 shows a summary of the mechanisms by which tobacco aggravates periodontal inflammation. The mechanism of immune inflammation that can accurately explain the aggravation and progression of periodontal disease with nicotine has not been fully elucidated. Nevertheless, oxidative stress and changes in the immune inflammatory system seem to play an important role.

Proteases from host and microorganism play an

Table 4. Tobacco exacerbates periodontal tissue inflammatory response

\begin{tabular}{|c|c|c|c|}
\hline Reference & $\begin{array}{l}\text { Vicrobiological } \\
\text { technique }\end{array}$ & Principal findings & Elfect on periodontal tissuce \\
\hline Deveci et al. ${ }^{33}$ & $\begin{array}{l}\text { Immunohistochemical } \\
\text { staining }\end{array}$ & $\begin{array}{l}\text { Up-regulate MMP-1, MMP-2 and MMP-3 } \\
\text { gene expression in arterial smooth muscle } \\
\text { cells, vascular endothelial cells, periodontal } \\
\text { ligament fibroblasts and osteoclasts }\end{array}$ & $\begin{array}{l}\text { MMPs are associated with periodontal tissue } \\
\text { destruction, which mainly degrade extracellular } \\
\text { matrix molecules such as collagen, gel, and } \\
\text { elastin }\end{array}$ \\
\hline Meenawat et al. ${ }^{68}$ & PCR & $\begin{array}{l}\text { Association of smoking status with } \\
\text { periodontal destruction is correlated with } \\
\text { the increased mRNA expression of IL-1 } \beta \text { in } \\
\text { chronic periodontitis patients }\end{array}$ & $\begin{array}{l}\text { Cytokines cause inflammatory responses that } \\
\text { exacerbate periodontal tissue destruction }\end{array}$ \\
\hline Johnson et al. ${ }^{69}$ & ELISA & $\begin{array}{l}\text { Nicotine promotes the secretion of IL- } 1 \text {, IL- } \\
6 \text {, IL- } 8 \text {, TNF and McP-1 by periodontal cells, } \\
\text { such as gingival keratinocytes and hGFs }\end{array}$ & \\
\hline Xanthoulea et al. ${ }^{71}$ & ELISA & $\begin{array}{l}\text { Nicotine injection affected inflammatory } \\
\text { mediators like TNF, IL- } 6 \text { and IL- } 12 \text { while } \\
\text { it induced a down-regulation in the } \\
\text { expression of VEGF, PDGF, TGF- } \beta 1 \text { and } \\
\text { TGF- } \beta 2 \text {, IL-10 }\end{array}$ & $\begin{array}{l}\text { Reduced growth factor expression by nicotine } \\
\text { might contribute to the overall detrimental } \\
\text { effects of tobacco use in wound healing }\end{array}$ \\
\hline Cho et al. ${ }^{73}$ & RT-PCR & $\begin{array}{l}\text { Nicotine and LPS synergistically induced } \\
\text { the production of COX-2 and PGE2 and } \\
\text { increased the protein expression of JAK/STAT }\end{array}$ & $\begin{array}{l}\text { PGF2 and COX-2 are associated with bone loss } \\
\text { in periodontitis, inducing MMPs and osteoclast } \\
\text { absorption }\end{array}$ \\
\hline
\end{tabular}


important role in periodontitis tissue destruction. Proteases break down proteins by hydrolyzing peptides. MMPs are a family of proteolytic enzymes associated with periodontal tissue destruction, which mainly degrade extracellular matrix molecules such as collagen, gel, and elastin ${ }^{31}$. Nicotine, which is the major ingredient of cigarette smoke, up-regulates MMP-1, MMP-2 and MMP-3 gene expression in arterial smooth muscle cells, vascular endothelial cells, periodontal ligament fibroblasts and osteoclasts. Nicotine administration also causes a change in fibroblast activity due to the change of collagen fiber synthesis and decreased MMP2 expression ${ }^{32}$.

Cytokines are proteins secreted by cells that act as information molecules to transmit signals to other cells. Cytokines have many roles, including initiation and maintenance of immune and inflammatory responses, regulating cell growth and differentiation. The two cytokines, interleukin (IL) and tumor necrosis factor (TNF), play an important role in periodontal tissue destruction. Association of smoking status with periodontal destruction can thus be correlated with the increased mRNA expression of IL-1 $\beta$ in chronic periodontitis patients ${ }^{67}$. A number of studies demonstrated that nicotine differentially regulate IL-1, IL-6, IL-8, TNF and MCP-1 production by periodontal cells, such as gingival keratinocytes and $\mathrm{hGFs}^{68,69}$. Nicotine injection in excisional fullthickness skin wounds minimally affects inflammatory mediators such as TNF, IL- 6 and IL-12, while it induces a down-regulation in the expression of growth factors such as VEGF, PDGF, TGF- $\beta 1$ and TGF- $\beta 2$, and the anti-inflammatory cytokine IL- $10^{70}$.
Reduced growth factor expression by nicotine might contribute, at least in part, to the overall detrimental effects of tobacco use in wound healing and skin diseases.

Studies suggest that LPS and nicotine synergistically induce the production of cyclooxgenase-2 (COX-2) and prostaglandin E2 (PGE2) and increase JAK/ STAT protein expression. Treatment with a JAK inhibitor blocks the production of COX-2 and PGE2 and the expression of pro-inflammatory cytokines, such as TNF- $a$, IL- $1 \beta$, and IL-6 in LPS- and nicotinestimulated osteoblasts ${ }^{71,72}$. PGE2 is associated with bone loss in periodontal disease, inducing MMPs and osteoclast absorption.

\section{Effect of tobacco on the alveolar bone}

Smoking produces an adverse effect on clinical periodontal variables and alveolar bone height and density, acting as a potential risk factor for alveolar bone $\operatorname{loss}^{73,74}$. These observations highlight the destruction of periodontal tissue by smoking and the unfavorable clinical course of periodontal disease in patients with a cigarette smoking habit. Table 5 summarizes the effect of tobacco on the alveolar bone.

Smoking alters alveolar bone metabolism and therefore can synergistically act on alveolar bone $\operatorname{loss}^{75}$. Hapidin et al. ${ }^{76}$ showed that nicotine significantly decreased the trabecular bone volume, trabecular thickness, double-labeled surface, mineralizing surface, mineral appositional rate, and bone formation rate, while causing an increase in the single-labeled surface, osteoclast surface, and eroded surface. Eratilla et al. ${ }^{77}$ found that nicotine

\section{Table 5. The effect of tobacco on the alveolar bone}

\begin{tabular}{|c|c|c|}
\hline Reference & $\begin{array}{l}\text { Vicrobiological } \\
\text { technique }\end{array}$ & Principal findlings \\
\hline Kubota et al. ${ }^{84}$ & RT-PCR & $\begin{array}{l}\text { CSE and Nicotine increased the number of osteoclasts and upregulated the expression } \\
\text { of receptor activator of nuclear factor } \mathrm{KB} \text { ligand }\end{array}$ \\
\hline Wu et al. ${ }^{85}$ & ELISA & $\begin{array}{l}\text { Nicotine has the ability to act on osteoclast precursors, inducing its osteoclastogenic } \\
\text { differentiation }\end{array}$ \\
\hline Costa-Rodrigues et al. ${ }^{86}$ & RT-PCR & $\begin{array}{l}\text { In the presence of the growth factors, the osteoclastogenesis enhancers M-CSF and } \\
\text { RANKL a significant increase in their resorbing ability is also achieved }\end{array}$ \\
\hline Saito et al. ${ }^{88}$ & Micro-CT & Nicotine can inhibit osteoblast differentiation \\
\hline Katono et al. ${ }^{89}$ & $\begin{array}{l}\text { Immunohistochemical } \\
\text { Staining }\end{array}$ & $\begin{array}{l}\text { Culture of nicotine and osteoblasts Saos-2 Cells significantly increase in the } \\
\text { expression of MMP }\end{array}$ \\
\hline Tura-Ceide et al. ${ }^{92}$ & RT-PCR & $\begin{array}{l}\text { Tobacco is associated with lower numbers of circulating stem cells, which affects the } \\
\text { homing and functional capabilities of bone marrow-derived mesenchymal stem cells }\end{array}$ \\
\hline
\end{tabular}


can cause alveolar bone absorption and vascular dilatation, hemorrhage, periodontal degeneration, hyaluronosis, and necrosis. Nicotine also affects bone remodeling during orthodontic movement, reducing angiogenesis, osteoclast-like cells and Howship's lacunae, thereby delaying the collagen maturation process in developed bone matrix ${ }^{78,79}$. Furthermore, cigarette smoking has a detrimental effect on early bone tissue response around sandblasted acid-etched implant surface topographies and narghile smoking increases peri-implant soft-tissue inflammation and crestal bone $\operatorname{loss}^{80-82}$. Overall, tobacco accelerates the loss of alveolar bone and has a negative effect on the remodeling of alveolar bone during implantation and orthodontic treatment proportional to the dose of CSE and nicotine.

Osteoclast and osteoblast play a key role in bone resorption caused by periodontal disease. Tooth loss is mainly a result of alveolar bone resorption, which reflects an increased osteoclast formation and activation. Kubota et al. ${ }^{83}$ reported that the systemic administration of cigarette smoke condensate or nicotine increases alveolar bone loss. Concomitantly, the number of osteoclasts in periodontal tissues increases and the expression of receptor activator of nuclear factor $\mathrm{kB}$ ligand is up-regulated. Osteoclast formation in periodontal tissue is a multi-step process driven by osteoclastogenesis, supporting cells such as human periodontal ligament cells and $\mathrm{CD} 4+\mathrm{T}$ cells, and inflammatory cytokines that induce osteoclastogenesis ${ }^{84}$. Thus, nicotine at levels found in the plasma of the smokers, has the ability to act directly on osteoclast precursors, inducing its osteoclastogenic differentiation, while in the presence of growth factors such as inflammatory cytokines, the osteoclastogenesis enhancers M-CSF and RANKL induce a significant resorbing increase ${ }^{85}$. Nicotine, which is the major ingredient of cigarette smoke, can also inhibit osteoblast differentiation ${ }^{86,87}$. Katono et al. ${ }^{88}$ found a significant increase in the expression of MMP after culture of nicotine and osteosarcoma Saos2 possessing several osteoblastic features. MMP-2 levels were higher in the exposed rats compared with the non-exposed rats, suggesting that MMP may be one of the molecules responsible for the increased tissue degradation observed in the periodontal tissues of smokers. MMP is considered as an important factor in periodontal tissue damage because of strong matrix degradation ability. Nicotine may accelerate the metabolic rate of the bone matrix by increasing the formation of MMP, which can affect osteoclast migration and adhesion and cause osteoblastic apoptosis, there by destroying the dynamic balance of bone formation and absorption.

A number of experimental animal studies and in vitro studies confirmed that nicotine impairs bone healing, diminishes osteoblast function, causes autogenous bone graft morbidity, and decreases graft biomechanical properties ${ }^{87,89}$. Some studies show that CSE and nicotine are also associated with a lower number of circulating stem cells and may severely affect their mobilization, trafficking and homing, consequently affecting the homing and functional capabilities of bone marrow-derived mesenchymal stem cells that are closely related to alveolar bone healing ${ }^{90,91}$. De Campos et al. ${ }^{92}$ aimed at evaluating the influence of smoking on gene expression of molecules related to bone metabolism in alveolar bone tissue from sites designed to receive dental implants. Multiple regression analysis indicated that smoking negatively affects mRNA expression of bone sialoprotein and osteocalcin and positively alters the expression of type I collagen despite age, gender, and dental arch. These results support the hypothesis that some bone markers in alveolar tissue are modulated by smoking, thus explaining the negative impact of smoking on bone healing.

\section{Effect of tobacco on tooth germ}

The negative effects of tobacco on periodontal disease may begin earlier than we thought, during tooth germ development. Saad et al. ${ }^{93}$ proposed that nicotine, or its metabolic byproducts, lead to retarded, less differentiated, and breadth reduced developing molars of the experimental mice fetuses in comparison with controls with no nicotine treatment. Wang et al. ${ }^{94,95}$ studied the effect of nicotine on dental germ development of mouse molar in vitro, and they found that nicotine inhibits the secretion of bone morphogenetic protein (BMP) in dental germ of mouse and dental papilla mesenchymal cells. They found also a reduced volume of developing tooth germ, a lower number and rapidity of odontoblast proliferation compared to the group with no nicotine treatment, with a decreased or inhibited formation of predentin. 
Tobacco and its metabolic byproducts interfere with the normal interaction between epithelial and mesenchymal components of the developing tooth, having teratogenic effects on the tooth, becoming a local factor promoting the occurrence and development of periodontal disease. On the other hand, smoking causes a reduction in tooth germ number, cell proliferation inhibition and differentiation, and reduced tooth number resulting in a potential negative effect on the prognosis of periodontal disease. An epidemiological study in Japan suggested that, maternal smoking in the first trimester of pregnancy is significantly associated with an increased prevalence of dental caries in children compared with children from non-smoking mothers during pregnancy ${ }^{96}$. However, epidemiological studies of the association between smoking exposure and periodontal disease during pregnancy are limited.

\section{Relationship between tobacco, periodontal disease and oral cancer}

Oral cavity cancer is a debilitating and often fatal cancer closely linked to tobacco product use. Smoking has a significant epidemiological correlation with oral cancer and plays an important role in its occurrence and development. Smokers are 7 to 10 times more likely to develop oral cancer and 3 times more likely to develop a second primary cancer than nonsmokers ${ }^{20,21}$. The devastating link between tobacco products and human cancers results from a powerful alliance of two factors - nicotine and carcinogens. Nicotine is addictive and toxic, but there is no scientific evidence that nicotine is a carcinogen, and nicotine is not classified as a carcinogen by the IARC. However, this addiction causes people to use tobacco products continually, and these products contain many carcinogens. There are more than 60 carcinogens in cigarette smoke and at least 16 in unburned tobacco. Among these, tobacco-specific nitrosamines such as 4-(methylnitrosamino)-1-(3-pyridyl)-1-butanone (NNK) and N'-nitrosonornicotine (NNN), polycyclic aromatic hydrocarbons (such as benzoapyrene) and aromatic amines (such as 4-aminobiphenyl) seem to play an important role as causes of oral cancer ${ }^{97}$.

Recently, several studies reported the relationship between periodontal disease and oral cancer. Some studies reported a positive association between periodontal disease and oral cancer after adjustment for potential confounders for several factors including age, gender, smoking status, and alcohol consumption, and suggested that periodontal disease is an independent risk factor for oral cancer, while smoking modifies this association ${ }^{22-26}$. However, other studies reported no association between periodontal disease and oral cancer ${ }^{98}$. The conclusion regarding the relationship between periodontal disease and oral cancer is still controversial. A systematic review by Javed $^{99}$ suggested a correlation between periodontal disease and oral tumors, and this association changes after adjusting for confounding factors such as tobacco and alcohol. Prior to this work, some other reports also agree with this view ${ }^{100,101}$. In addition, many published meta-analyses are available that illustrate this problem. Some of the published metaanalyses in recent years are listed in Table $6^{102-104}$. It is noteworthy that some of the periodontal disease risk factors, particularly tobacco and betel quid use, have also been linked with the etiology of oral cancer. Although in some small studies, tobacco or alcohol use and socioeconomic confounders attenuate the association between periodontitis and oral cancer, overall findings of a recent systematic review concluded that periodontitis is likely to be associated with increased head and neck cancer risk ${ }^{105}$.

In summary, there is only scarce evidence that periodontal disease may be related to the prevalence of oral cancer. Nevertheless, the association of periodontal disease to oral neoplasms may be

Table 6. Oral cancer is associated with periodontal disease

\begin{tabular}{|c|c|c|c|c|}
\hline Reference & Sample & OR & $95 \%$ CI & Conclusion \\
\hline Ye et al. ${ }^{103}$ & 11 case-control studies & 3.21 & $\begin{array}{l}2.25-4.16 \\
p<0.05\end{array}$ & $\begin{array}{l}\text { Periodontal disease can increase the oral cancer risk by } \\
\text { nearly 2-fold }\end{array}$ \\
\hline Yao et al. ${ }^{104}$ & 5 case-control studies & 3.53 & $\begin{array}{l}1.52-8.23 \\
p=0.003\end{array}$ & $\begin{array}{l}\text { Patients with periodontal disease have increased } \\
\text { susceptibility to oral cancer }\end{array}$ \\
\hline Zeng et al. ${ }^{105}$ & $\begin{array}{l}2 \text { cohort and } 6 \text { case-control } \\
\text { studies }\end{array}$ & 2.63 & $\begin{array}{l}1.1 .68-4.14 \\
p<0.001\end{array}$ & $\begin{array}{l}\text { Based on currently evidence, PD is probably a significant and } \\
\text { independent risk factor of HNC }\end{array}$ \\
\hline
\end{tabular}


explained indirectly by the possibility that a broken mucosal barrier in the presence of periodontal disease could lead to a subsequent penetration of carcinogens such as tobacco and alcohol. The association between periodontitis and oral cancer does not rule out a link between tobacco and oral cancer, and further investigation is warranted.

A smoker absorbs half a milligram of nicotine in each cigarette, which is degraded to cotinine (the major metabolite close to nicotine), nicotine glucuronide, nircotrine and nornicotine primarily ${ }^{106}$. Nicotine possesses a very short half-life in the blood, approximately $2 \mathrm{~h}$, while cotinine, a major metabolite of nicotine with a longer half-life ( $17 \mathrm{~h}$ vs $30 \mathrm{~min})$, may be a more useful biochemical marker of smoking status ${ }^{107}$. Cotinine has been widely used as a stable biomarker of tobacco exposure and has been used to correlate its levels with periodontal disease severity ${ }^{108,109}$.

It should be made clear that most of the findings described are from experimental studies in cell cultures and not from human studies. Some experimental studies used exposure to CSE, but others have used nicotine instead of tobacco. Although nicotine is the major ingredient of cigarette smoke, what tobacco does to human health cannot be attributed to nicotine alone as there are so many molecules contained in tobacco smoke. Tobacco metabolism in the body will lead to dynamic changes in its concentration and it is difficult to simulate the real situation with in vitro experiments, adding difficulties to the evaluation of human applicability and effectiveness of the conclusions. Accurate and reliable measurements of exposure to tobacco products are essential for identifying and confirming patterns of tobacco product use and for assessing their potential biological effects in both human populations and experimental systems. This is also a difficult research problem worldwide that needs further study.

\section{CONCLUSIONS}

Periodontal disease is one of the major dental pathologies and it is also a multifactorial disease that involves microbial challenge and host responses. Cigarette smoking is a well-established risk factor for periodontal disease. Both active and passive smoking could aggravate the development of periodontal disease. Tobacco can directly damage periodontal ligament cells, accelerate the loss of alveolar bone and negatively affect the remodeling of alveolar bone during implantation and orthodontic treatment. Lower concentrations of CSE could promote the biofilm formation of the bacteria-related periodontal disease and have the potential to elicit a stress reaction, thus potentially working as an environmental modulating factor for bacterial metabolism and survival.

From the evidence available at present, tobacco significantly increases the prevalence of oral cancer and aggravates the damage from periodontal disease. But the evidence that periodontal disease may be related to the prevalence of oral cancer is limited. The in vitro experiments are not sufficient to link the effects of tobacco to periodontal disease given the complexity of host response. The mechanisms of tobacco in the exacerbation and progression of periodontal disease and the specific molecular mechanisms linking periodontal disease and oral cancer need to be further explored.

\section{REFERENCES}

1. Razavi SM, Siadat S, Rahbar P, Hosseini SM, Shirani AM. Trends in oral cancer rates in Isfahan, Iran during 19912010. Dent Res J (Isfahan). 2012;9(Suppl 1):S88-S93.

2. Sutton JD, Salas Martinez ML, Gerkovich MM. Environmental Tobacco Smoke and Periodontitis in United States Non-Smokers, 2009 to 2012 . J Periodontol. 2017;88(6):565-574. doi:10.1902/jop.2017.160725

3. Akinkugbe AA, Sanders AE, Preisser JS, Cai J, Salazar CR, Beck JD. Environmental tobacco smoke exposure and periodontitis prevalence among nonsmokers in the hispanic community Health Study/Study of Latinos. Community dentistry and oral epidemiology. 2017;45(2):168-177. doi: 10.1111/cdoe.12275

4. Akinkugbe AA, Slade GD, Divaris K, Poole C. Systematic Review and Meta-analysis of the Association Between Exposure to Environmental Tobacco Smoke and Periodontitis Endpoints Among Nonsmokers. Nicotine $\&$ tobacco research: official journal of the Society for Research on Nicotine and Tobacco. 2016;18(11):20472056. doi: $10.1093 / \mathrm{ntr} / \mathrm{ntw} 105$

5. Dietrich T, Walter C, Oluwagbemigun K, et al. Smoking, Smoking Cessation, and Risk of Tooth Loss: The EPICPotsdam Study. J Dent Res. 2015;94(10):1369-1375. doi:10.1177/0022034515598961

6. Ozden FO, Ozgonenel O, Ozden B, Aydogdu A. Diagnosis of periodontaldiseases using different classification algorithms: a preliminary study. Niger J Clin Pract. 2015;18(3):416-421. doi:10.4103/1119-3077.151785

7. Pihlstrom BL, Michalowicz BS, Johnson NW. Periodontal diseases. Lancet. 2005;366(9499):1809-1820. 
doi:10.1016/s0140-6736(05)67728-8

8. Genco RB, Borgnakke WS. Risk factors for periodontal disease. Periodontology 2000. 2013;62(1):59-94. doi: 10.1111/j.1600-0757.2012.00457.x

9. Pindborg JJ. Tobacco and gingivitis: I. Statistical examination of the significance of tobacco in the development of ulceromembranous gingivitis and in the formation of calculus. J Dent Res. 1947;26:261-264.

10. Pindborg JJ . Tobacco and gingivitis: II. Correlation between consumption of tobacco, ulceromembranous gingivitis and calculus. J Dent Res. 1949;28(5):460-463. doi:10.1177/00220345490280050601

11. Haber J, Wattles J, Crowley M, Mandell R, Joshipura K, Kent RL. Evidence for cigarette smoking as a major risk factor for periodontitis. J Periodontol. 1993;64(1):1623. doi:10.1902/jop.1993.64.1.16

12. Vouros ID, Kalpidis C, Chadjipantelis T, Konstantinidis AB. Cigarette smoking associated with advanced periodontal destruction in a Greek sample population of patients with periodontal disease. J Int Acad Periodontol. 2009;11:250-257.

13. Yanagisawa T, Ueno M, Shinada K, Ohara S, Wright FA, Kawaguchi Y. Relationship of smoking and smoking cessation with oral health status in Japanese men. Journal of periodontal research. 2019;45(2):277-283. doi:10.1111/j.1600-0765.2009.01233.x

14. Krall EA, Garvey AJ, Garcia RI. Alveolar bone loss and tooth loss in male cigar and pipe smokers. J Am Dent Assoc. 1999;130(1):57-64. doi:10.14219/jada.archive.1999.0029

15. Leung WK Ng DK, Jin L, Corbet EF. Tooth loss in treated periodontitis patients responsible for their supportive care arrangements. J Clin Periodontol. 2006;33:265575. doi:10.1111/j.1600-051X.2006.00903.x

16. Flouris AD Koutedakis Y. Immediate and short-term consequences of secondhand smoke exposure on the respiratory system. Curr Opin Pulm Med. 2011;17(2):110115. doi:10.1097/mcp.0b013e328343165d

17. Chi AC, Day TA, Neville BW. Oral cavity and oropharyngeal squamous cell carcinoma - an update. CA Cancer J Clin. 2015;65(5):401-421. doi: $10.3322 /$ caac. 21293

18. Chang TS CC, Ho HC, Su YC, Chen LF, Chou P. Impact of young age on the prognosis for oral cancer: a population-based study in Taiwan. PloS one. 2013;8(9):e75855

19. Warnakulasuriya S. Global epidemiology of oral and oropharyngeal cancer. Oral Oncol. 2009;45(4-5):309316. doi:10.1016/j.oraloncology.2008.06.002

20. Warnakulasuriya S, Sutherland G, Scully C.Tobacco, oral cancer, and treatment of dependence. Oral Oncol. 2005;41(3):244-260. doi:10.1016/j.oraloncology.2004.08.010

21. Esfahrood ZR, Zamanian A, Torshabi M, Abrishami $M$. The effect of nicotine and cotinine on human gingival fibroblasts attachment to root surfaces. J Basic Clin Physiol Pharmacol. 2015;26(5):517-522. doi:10.1515/jbcpp-2014-0120

22. Tezal M, Sullivan M, Reid ME, et al. Chronic periodontitis and the risk of tongue cancer. Arch Otolaryngol Head Neck Surg. 2007;133(5):450-454. doi:10.1001/archotol.133.5.450

23. Tezal M, Sullivan MA, Hyland A, et al. Chronic periodontitis and the incidence of head and neck squamous cell carcinoma. Cancer Epidemiol Biomarkers Preventon. 2009;18(9):2406-2412. doi:10.1158/1055-9965.epi-09-0334

24. Ansai T, TakataY, Yoshida A, et al. Association between tooth loss and orodigestive cancer mortality in an 80-year-old community-dwelling Japanese population: a 12-year prospective study. BMC Public Health. 2013;13(1):814. doi: 10.1186/1471-2458-13-814

25. Rezende CP, Ramos MB, Daguíla CH, Dedivitis RA, Rapoport A. Oral health changes in with oral and oropharyngeal cancer. Braz J Otorhinolaryngol. 2008;74(4):596-600. doi:10.1016/s1808-8694(15)30609-1

26. Rosenquist K, Wennerberg J, Schildt EB, Bladström A, Göran Hansson B, Andersson G. Oral status, oral infections and some lifestyle factors as risk factors for oral and oropharyngeal squamous cell carcinoma. A population-based case-control study in southern Sweden. Acta Otolaryngol.2005;125(12):1327-1336. doi:10.1080/00016480510012273

27. Chang YC, Huang FM, Tai KW, Yang LC, Chou MY. Mechanisms of cytotoxicity of nicotine in human periodontal ligament fibroblast cultures in vitro.J Periodont Res. 2002;37(4):279-285. doi:10.1034/j.1600-0765.2002.01612.x

28. Lallier TE, Moylan JT, Maturin E. Greater sensitivity of oral fibroblasts to smoked versus smokeless tobacco. Journal of periodontology. 2017;88(12):1356-1365.

29. Du Y, Yong S, Zhou Z, et al. [A preliminary study on the autophagy level of human periodontal ligament cells regulated by nicotine]. West China journal of stomatology. 2017;35(2):198-202. doi: 10.7518/hxkq.2017.02.017

30. Zhang W, Song F, Windsor LJ. Effects of Tobacco and P. gingivalis on Gingival Fibroblasts. Journal of Dental Research. 2010;89(5):527-31. doi:10.1177/0022034509358567

31. Zhou J, Olson BL, Windsor LJ. Nicotine increases the collagen-degrading ability of human gingival fibroblast. J Periodont Res 2007;42:228-235. doi:10.1111/j.1600-0765.2006.00937.x

32. Deveci B, Ayna B, Tacir IH, Deveci E, Tuncer MC, Pala A. Effects of nicotine administration in rats on MMP2 and VEGF levels in periodontal membrane. Folia morphologica. 2018;77(3):471-477. doi:10.5603/FM.a2018.0004

33. Park GJ, Kim YS, Kang KL, et al. Effects of sirtuin 1 
activation on nicotine and lipopolysaccharide-induced cytotoxicity and inflammatory cytokine production in human gingival fibroblasts. Journal of periodontal research. 2013;48(4):483-492. doi:10.1111/jre.12030

34. Thuong NV, Hall LL, Gallacher G, et al. Choline acetyltransferase, acetylcholinesterase, and nicotinic acetylcholine receptors of human gingival and esophageal epithelia. J Dent Res. 2000;79(4):939-949. doi:10.1177/00220345000790040901

35. Brejc K, van Dijk WJ, Klaassen RV, et al. Crystal structure of an ach-binding protein reveals the ligand-binding domain of nicotinic receptors. Nature. 2001;411(6835):269-276. doi:10.1038/35077011

36. Faruk ER, Deveci E, Kalkanli S, Deveci B. The effects of nicotine on the incisive teeth and expression of vimentin in rats. Int. J. Morphol. 2013;31(2):516-519. doi:10.4067/s0717-95022013000200026

37. Moga M, Bosca AB, Soritau O. Nicotine cytotoxicity on the mesenchymal stem cells derived from human periodontium. Romanian biotechnological letters. 2016;21(4):11763-11772.

38. Ng T, Huang L, Cao D, et al. Cigarette smoking hinders human periodontal ligament-derived stem cell proliferation, migration and differentiation potentials. Scientific reports. 2015;5(1):7828. doi:10.1038/srep07828

39. White DJ. Dental calculus: recent insights into occurrence, formation, prevention, removal and oral health effects of supragingival and subgingival deposits. Eur J Oral Sci. 1997;105:508-522. doi:10.1111/j.1600-0722.1997.tb00238.x

40. Hutcherson JA, Scott DA, Bagaitkar J. Scratching the surface - tobacco-induced bacterial biofilms. Tob Induc Dis. 2015;13(1):1. doi:10.1186/s12971-014-0026-3

41. Apatzidou DA, Riggio MP, Kinane DF. Impact of smoking on the clinical, microbiological and immunological parameters of adult patients with periodontitis. J Clin Periodontol. 2005;32(9):973-983. doi:10.1111/j.1600-051x.2005.00788.x

42. Salvi GE, Ramseier CA, Kandylaki M, Sigrist L, Awedowa E, Lang NP. Experimental gingivitis in cigarette smokers: a clinical and microbiological study. J Clin Periodontol. 2005;32(5):441-447. doi:10.1111/j.1600-051x.2005.00691.x

43. Cogo K, Montan FM, Bergamaschi CC, Andrade ED, Rosalen PL, Groppo FC. In vitro evaluation of the effect of nicotine, cotinine, and caffeine on oral microorganisms. Canadian journal of microbiology. 2008;54(6):501-508. doi:10.1139/w08-032

44. Haffajee AD, Socransky SS. Relationship of cigarette smoking to the subgingival microbiota. J Clin Periodontol. 2001;28(5):377-388. doi:10.1034/j.1600-051x.2001.028005377.x

45. Huang R, Li M, Ye M, Yang K, Xu X, Gregory RL. Effects of Nicotine on Streptococcus gordonii Growth, Biofilm Formation, and Cell Aggregation. Applied and environmental microbiology. 2014;80(23):7212-7218. doi: 10.1128/AEM.02395-14

46. Shan G, Wan Harun H-A. Influence of nicotine on the adherence of Candida albicans ATCC 14053 and Candida parapsilosis ATCC 22019 and expression of selected binding-related genes. Biotechnology \& Biotechnological Equipment. 2017:1-8. doi:10.1080/13102818.2017.1334593

47. Grossi SG, Goodson JM, Gunsolley JC, et al. Mechanical therapy with adjunctive minocycline microspheres reduces red-complex bacteria in smokers. J Periodontol. 2007;78(9):1741-1750. doi:10.1902/jop.2007.070118

48. Cogo K, Calvi BM, Mariano FS, Franco GC, Goncalves RB, Groppo FC. The effects of nicotine and cotinine on Porphyromonas gingivalis colonisation of epithelial cells. Archives of oral biology. 2009;54(11):1061-1067. doi:10.1016/j.archoralbio.2009.08.001

49. Liu S, Tian M, Shi L, Pan W, Wang X, Li M. Effect of nicotine and mecamylamine on growth of periodontal pathogens. Journal of international stomatology. 2017;44(4):421-425.

50. Cogo K, de Andrade A, Labate CA, et al. Proteomic analysis of Porphyromonas gingivalis exposed to nicotine and cotinine. Journal of periodontal research. 2012;47(6):766775. doi:10.1111/j.1600-0765.2012.01494.x

51. Baek O, Zhu W, Kim HC, Lee SW. Effects of nicotine on the growth and protein expression of Porphyromonas gingivalis. The Journal of Microbiology. 2012;50(1):143-148. doi:10.1007/s12275-012-1212-8

52. Bondy-Carey JL, Galicia J, Bagaitkar J, et al. Neutrophils alter epithelial response to Porphyromonas gingivalis in a gingival crevice model. Molecular oral microbiology. 2013;28(2):102-113. doi:10.1111/omi.12008

53. Nakagawa I, Inaba H, Yamamura T, et al. Invasion of epithelial cells and proteolysis of cellular focal adhesion components by distinct types of Porphyromonas gingivalis fimbriae. Infection and immunity. 2006;74(7):3773-3782. doi:10.1128/iai.01902-05

54. Imamura K, Kokubu E, Kita D, Ota K, Ishihara K, Saito A. Cigarette smoke condensate modulates migration of human gingival epithelial cells and their interactions with Porphyromonas gingivalis. Journal of periodontal research. 2015;50(3):411-421. doi:10.1111/jre.12222

55. Imamura K, Kokubu E, Kita D, et al. Role of mitogenactivated protein kinase pathways in migration of gingival epithelial cells in response to stimulation by cigarette smoke condensate and infection by Porphyromonas gingivalis. Journal of periodontal research. 2016;51(5):613-621. doi:10.1111/jre.12341

56. White PC, Hirschfeld J, Milward MR, et al. Cigarette smoke modifies neutrophil chemotaxis, neutrophil extracellular trap formation and inflammatory responserelated gene expression. Journal of periodontal research. 2018;53:525-535. doi:10.1111/jre.12542

57. Erdemir EO DI, Duran I, Haliloglu S. Effects of smoking 
on clinical parameters and the gingival crevicular fluid levels of IL-6 and TNF-alpha in patients with chronic periodontitis. J Clin Periodontol. 2014;31(2):99-104. doi:10.1111/j.0303-6979.2004.00454.x

58. Honda T Domon H, Okui T, Kajita K, Amanuma $\mathrm{R}$, Yamazaki K. Balance of inflammatory response in stable gingivitis and progressive periodontitis lesions. Clin Exp Immunol. 2006;144:35-40. doi:10.1111/j.1365-2249.2006.03028.x

59. Ge X, Liu YF, Wong Y, et al. Impact of nicotine on the interplay between human periodontal ligament cells and CD4+ T cells. Human \& experimental toxicology. 2016;35(9):983-990. doi: 10.1177/0960327115614383

60. Yanagita M, Mori K, Kobayashi R, et al. Immunomodulation of dendritic cells differentiated in the presence of nicotine with lipopolysaccharide from Porphyromonas gingivalis. European journal of oral sciences. 2012;120(5):408-414. doi: 10.1111/j.1600-0722.2012.00992.x.

61. An N, Andrukhov O, Tang Y, et al. Effect of nicotine and porphyromonas gingivalis lipopolysaccharide on endothelial cells in vitro. PloS one. 2014;9(5):e96942. doi:10.1371/journal.pone.0096942

62. Bozkurt FY, Yetkin Ay Z, Sutcu R, Delibas N, Demirel R. Gingival crevicular fluid leptin levels in periodontitis patients with long-term and heavy smoking. J Periodontol. 2006;77(4):634-640. doi:10.1902/jop.2006.050277

63. Hwang SJ. Influence of smoking cessation on periodontal biomarkers in gingival crevicular fluid for 1 year: A case study. Journal of dental hygiene science. 2014;14(4):525-536. doi:10.17135/jdhs.2014.14.4.525

64. Bunaes DF, Mustafa M, Mohamed HG, Lie SA, Leknes $\mathrm{KN}$. The effect of smoking on inflammatory and bone remodeling markers in gingival crevicular fluid and subgingival microbiota following periodontal therapy. Journal of periodontal research. 2017;52(4):713-724. doi:10.1111/jre.12438

65. Moon KA, Rule AM, Magid HS, et al. Biomarkers of Secondhand Smoke Exposure in Waterpipe Tobacco Venue Employees in Istanbul, Moscow, and Cairo. Nicotine \& tobacco research: official journal of the Society for Research on Nicotine and Tobacco. 2018;20(4):482-491. doi:10.1093/ntr/ntx125

66. Souto GR, Queiroz-Junior CM, Costa FO, Mesquita RA. Effect of smoking on immunity in human chronic periodontitis. Immunobiology. 2014;219(12):909-915. doi:10.1016/j.imbio.2014.08.00

67. Meenawat A, Govila V, Goel S, et al. Evaluation of the effect of nicotine and metabolites on the periodontal status and the mRNA expression of interleukin-1beta in smokers with chronic periodontitis. Journal of Indian Society of Periodontology. 2015;19(4):381-387. doi:10.4103/0972-124X.157879

68. Johnson GK, Guthmiller JM, Joly S, Organ CC, Dawson
DV. Interleukin-1 and interleukin-8 in nicotine- and lipopolysaccharide-exposed gingival keratinocyte cultures. Journal of periodontal research. 2010;45(4):583-588. doi:10.1111/j.1600-0765.2009.01262.x

69. Almasri A, Wisithphrom K, Windsor LJ, Olson B. Nicotine and lipopolysaccharide affect cytokine expression from gingival fibroblasts. J Periodontol. 2007;78(3):533-541. doi:10.1902/jop.2007.060296

70. Xanthoulea S, Deliaert A, Romano A, Rensen SS, Buurman WA, van der Hulst RR. Nicotine effect on inflammatory and growth factor responses in murine cutaneous wound healing. International immunopharmacology. 2013;17(4):1155-1164. doi:10.1016/j.intimp.2013.10.022

71. Han YK, Lee IS, Lee S. Jak/stat pathway modulates on porphyromonas gingivalis lipopolysaccharideand nicotine-induced inflammation in osteoblasts. Journal of Dental Hygiene Science. 2017;17(1):81-86. doi:10.17135/jdhs.2017.17.1.81

72. Cho YA, Jue SS, Bae WJ, et al. PIN1 inhibition suppresses osteoclast differentiation and inflammatory responses. J Dent Res. 2015;94(2):371-380. doi:10.1177/0022034514563335

73. Rosa GM, Lucas GQ, Lucas ON. Cigarette smoking and alveolar bone in young adults: a study using digitized radiographs. J Periodontol. 2008;79(2):232-244. doi: 10.1902/jop.2008.060522

74. Javed F, Al-Kheraif AA, Rahman I. Comparison of clinical and radiographic periodontal status between habitual water-pipe smokers and cigarette smokers. Journal of periodontology. 2016;87(2):142-147. doi:10.1902/jop.2015.150235

75. Campos ML, Correa MG, Junior FH, Casati MZ, Sallum EA, Sallum AW. Cigarette smoke inhalation increases the alveolar bone loss caused by primary occlusal trauma in a rat model. Journal of periodontal research. 2014;49(2):179-185. doi:10.1111/jre.12091

76. Hapidin H, Othman F, Soelaiman IN, Shuid AN, Luke DA, Mohamed N. Negative effects of nicotine on bone-resorbing cytokines and bone histomorphometric parameters in male rats. Journal of bone and mineral metabolism. 2007;25(2):93-98. doi:10.1007/s00774-006-0733-9

77. Eratilla V, Uysal I, Ozevren H. Effects of nicotineon rat alveolar bone. Analytical and quantitative. Cytopathology and histopathology. 2016;38(5):277282.

78. Shintcovsk RL, Knop L, Tanaka OM, Maruo H. Nicotine effect on bone remodeling during orthodontic tooth movement: Histological study in rats. Dental Press Journal of Orthodontics. 2014;19(2):96-107. doi:10.1590/2176-9451.19.2.096-107.oar

79. Kirschneck C, Proff P, Maurer M, Reicheneder C, Romer P. Orthodontic forces add to nicotine-induced loss of periodontal bone: An in vivo and in vitro study. 
Journal of orofacial orthopedics. 2015;76(3):195-212. doi:10.1007/s00056-015-0283-7

80. Chrcanovic BR, Albrektsson T, Wennerberg A. Smoking and dental implants: A systematic review and metaanalysis. Journal of dentistry. 2015;43(5):487-498 doi:10.1016/j.jdent.2015.03.003

81. Bezerra Ferreira JD, Rodrigues JA, Piattelli A, Iezzi G, Gehrke SA, Shibli JA. The effect of cigarette smoking on early osseointegration of dental implants: a prospective controlled study. Clinial oral implants research. 2016;27(9):1123-1128 doi:10.1111/clr.12705

82. Abduljabbar T, Al-Hamoudi N, AlQunayan M. Periimplant soft-tissue parameters and crestal bone levels among narghile smokers and nonsmokers. Inhalation toxicology. 2017;29(10):457-461. doi:10.1080/08958378.2017.1394401

83. Kubota M, Yanagita M, Mori K, et al. The Effects of Cigarette Smoke Condensate and Nicotine on Periodontal Tissue in a Periodontitis Model Mouse. Plos one. 2016;11(5):e 0155594. doi:10.1371/journal.pone.0155594

84. Wu LZ, Duan DM, Liu YF, Ge X, Zhou ZF, Wang XJ. Nicotine favors osteoclastogenesis in human periodontal ligament cells co-cultured with CD4+ T cells by upregulating IL-1 $\beta$. International Journal of Molecular Medicine. 2013;31(4):938-942. doi:10.3892/ijmm.2013.1259

85. Costa-Rodrigues J, Rocha I, Fernandes MH. Complex osteoclastogenic inductive effects of nicotine over hydroxyapatite. Journal of cellular physiology. 2018;233(2):1029-1040. doi:10.1002/jcp.25956

86. Mody N, Parhami F, Sarafian TA, Demer LL. Oxidative stress modulates osteoblastic differentiation of vascular and bone cells. Free radical biology \& medicine. 2001;31(4):509-519. doi:10.1016/s0891-5849(01)00610-4

87. Saito Y, Sato S, Oginuma T, Saito Y, Arai Y, Ito K. Effects of nicotine on guided bone augmentation in rat calvarium. Clinical oral implants research. 2013;24(5):531-535. doi:10.1111/j.1600-0501.2011.02416.x

88. Katono T, Kawato T, Tanabe N, et al. Nicotine treatment induces expression of matrix metalloproteinases in human osteoblastic Saos-2 cells. Acta biochimica et biophysica Sinica. 2006;38(12):874-882. doi:10.1111/j.1745-7270.2006.00240.x

89. Yuhara S, Kasagi S, Inoue A, Otsuka E, Hirose S, Hagiwara H. Effects of nicotine on cultured cells suggest that it can influence the formation and resorption of bone. European journal of pharmacology. 1999;383(3):387393. doi:10.1016/s0014-2999(99)00551-8

90. Gong M, Liu J, Chou T. Perinatal nicotine exposure disrupts paracrine communication between bone marrow-derived mesenchymal stem cells and alveolar type ii cells transgenerationally. Journal of investigative medicine 2015;63(1):98.
91. Tura-Ceide O, Lobo B, Paul T, et al. Cigarette smoke challenges bone marrow mesenchymal stem cell capacities in guinea pig. Respiratory research. 2017;18(1):2-12 doi:10.1186/s12931-017-0530-0

92. De Campos JM, Prati AJ, Cirano FR, et al. Smoking modulates gene expression of type i collagen, bone sialoprotein, and osteocalcin in human alveolar bone. Journal of oral and maxillofacial surgery. 2015;73(11):2123-2131. doi:10.1016/j.joms.2015.06.168

93. Saad AYM, Gartner LP, Hiatt JL. Teratogenic effects of nicotine on first molar odontogenesis in the mouse. Acta morphologica hungarica. 1991;39(2):87-96.

94. Wang X, Wen L, Yang F. Effect of nicotine on mouse molar germ development in vitro. Chinese journal of conservative dentistry. 2004;14(3):130-133.

95. Wang X, Wen L, Yang F. The effect of nicotine on BMP secretion of mouse molar germ and dental papilla cells of in vitro. Chinese journal of conservative dentistry. 2004;14(3):134-136.

96. Tanaka K, Miyake Y, Nagata C. Association of prenatal exposure to maternal smoking and postnatal exposure to household smoking with dental caries in 3-yearold Japanese children. Environmental research. 2015;143:148-153. doi:10.1016/j.envres.2015.10.004

97. Hecht S. Tobacco carcinogens, their biomarkers and tobacco-induced cancer. Nat Rev Cancer. 2003;3(10):733-744. doi:10.1038/nrc1190

98. Divaris K OA, Smith J, Bell ME, et al. Oral health and risk for head and neck squamous cell carcinoma: the Carolina Head and Neck Cancer Study. Cancer Causes Control. 2010;21(4):567-575. doi:10.1007/s10552-009-9486-9

99. Javed F WS. Is there a relationship between periodontal disease and oral cancer? A systematic review of currently available evidence. Crit Rev Oncol Hematol. 2016;97:197-205. doi:10.1016/j.critrevonc.2015.08.018

100. Meyer MS, Joshipura K, Giovannucci E, Michaud DS. A review of the relationship between tooth loss, periodontal disease, and cancer. Cancer Causes Control. 2008;19(9):895-907. doi:10.1007/s10552-008-9163-4

101. Fitzpatrick SG, Katz, J. The association between periodontal disease and cancer: a review of the literature. J. Dent. 2010;38(2)83-95. doi:10.1016/j.jdent.2009.10.007

102. Ye L, Jiang Y, Liu W, Tao H. Correlation between periodontal disease and oral cancer risk: A metaanalysis. J Can Res Ther. 2016;12(8):237-240. doi:10.4103/0973-1482.200746

103. Yao QW Zhou DS, Peng HJ, Ji P, Liu DS. Association of periodontal disease with oral cancer:a metaanalysis. Tumour Biol. 2014;35(7):7073-7077. doi:10.1007/s13277-014-1951-8

104. Zeng XT, Deng AP, Li C, Xia LY, Niu YM, Leng WD. Periodontal disease and risk of head and neck cancer: a meta-analysis of observational studies. PloS one. 2013;8(10):e79017. doi:10.1371/journal.pone.0079017 
105. Javed F, Warnakulasuriya S. Is there a relationship between periodontaldisease and oral cancer? A systematic review of currently available evidence. Crit Rev Oncol Hematol. 2016;97:197-205. doi:10.1016/j.critrevonc.2015.08.018

106. Borgerding M, Klus H. Analysis of complex mixturescigarette smoke. Exp Toxicol Pathol. 2005;57(1):43-73. doi:10.1016/j.etp.2005.05.010

107. Benowitz NL. Cotinine as a biomarker of environmental tobacco smoke exposure. Epidemiol Rev. 1996;18(2):188-204. doi:10.1093/oxfordjournals.epirev.a017925

108. Ebersole JL, Steffen MJ, Thomas MV, Al-Sabbagh M. Smoking-related cotinine levels and host responses in chronic periodontitis. Journal of periodontal research. 2014;49(5):642-651. doi:10.1111/jre.12146

109. Duque A, Martinez PJ, Giraldo A, et al. Accuracy of cotinine serum test to detect the smoking habit and its association with periodontal disease in a multicenter study. Medicina Oral Patología Oral y Cirugia Bucal. Med Oral Patol Oral Cir Bucal. 2017;22(4):e425-31. doi:10.4317/medoral.21292

\section{CONFLICTS OF INTEREST}

Authors have completed and submitted the ICMJE Form for Disclosure of Potential Conflicts of Interest and none was reported.

\section{FUNDING}

This review was supported by the National Natural Science Foundation of China (81400501 to ML, 31800114 to RH and 81500811 to $B H$ ).

AUTHORS' CONTRIBUTIONS

$\mathrm{YZ}, \mathrm{RH}$ and $\mathrm{ML}$ contributed to the design, drafting and revision of the review. $\mathrm{JH}$ and $\mathrm{BH}$ contributed to the revision of the review.

PROVENANCE AND PEER REVIEW

Not commissioned; externally peer reviewed. 